\title{
Studi Pendahuluan Terhadap Populasi Ikan Banggai Cardinal(Pterapogon kauderni, Koumans 1933) di Perairan Teluk Ambon Dalam ${ }^{1}$
}

Preliminary Study on Banggai Cardinal Fish Square Population(Pterapogon kauderni, Koumans 1933) in Inner Ambon Bay ${ }^{1}$ \author{
COREMAP, 2018 \\ ${ }^{2}$ Loka Konservasi Biota Laut Bitung-LIPI \\ ${ }^{3}$ Pusat Penelitian Laut Dalam Ambon-LIPI \\ E-mail: amane_huwae@yahoo.co.id
}

Rikardo Huwae ${ }^{2}$,Simon I. Patty ${ }^{2}$, Ucu Yanu Arbi ${ }^{2}$ dan Jance Hehuwat ${ }^{3}$

${ }^{1}$ Penelitian non-detrimental finding (NDF)-Banggai Cardinalfish (BCF) di Ambon,Proyek Penelitian

\begin{abstract}
ABSTRAK
Pterapogon kaudernimerupakan salah satu spesies ikan hias laut endemik Indonesia yang memiliki nilai komersial yang cukup tinggi pada perdagangan ikan hias internasional. Populasi ikan inidi alamtelah nyata mengalami penurunan akibat dari penangkapan berlebihan tampa memperhatikan aspek biologis maupun ekologis.Pengamatanterhadap ikan Banggai Cardinaldi perairan Teluk Ambon Dalamdilakukan untuk mengetahui jumlah populasi dan dugaan stok ikan.Hasilnya menunjukkan bawa populasi ikan tertinggi terdapat pada lokasi Poka,dengan nilaidensitas0,17-0,42 ekor/m²dandugaan populasi mencapai 25411 ekor. Populasiikan terendah terdapat di Waiheru dengan densitas0,05-0,06 ekor/ $\mathrm{m}^{2}$ serta dugaan populasi mencapai 2556 ekor.Kelimpahan populasi ikanhias ini berhubungan erat dengan kelimpahan bulu babi yang merupakan mikrohabitat utamanya pada daerah lamun dan terumbu karang.
\end{abstract}

Kata kunci: Populasi, habitat, Pterapogon kauderni, Teluk Ambon Dalam.

\section{ABSTRACT}

Pterapogon kauderni is one of Indonesia's endemic marine ornamental fish species which has high commercial value in the international ornamental fish trade. The population of this fish in the natural habitat has markedly decreased due to overfishing with no regard to biological or ecological aspects. Observation of Banggai Cardinal fish in Inner Ambon Bay was carried out to determine the population size and estimated fish stocks. The results showed that the highest fish population was found in the Poka location with a density value of 0.17-0.42 tails $/ \mathrm{m}^{2}$ and the estimated population reached 25411 tails. The lowest fish population is in Waiheru with a density of 0.05-0.06 tails $/ \mathrm{m}^{2}$ and the estimated population reaches 2556 tails. The abundance of ornamental fish populations is closely related to abundance of sea urchins which is a micro habitat mainly in seagrass and coral reefs.

Keywords: Population, habitat, Pterapogon kauderni, Inner Ambon Bay. 


\section{Pendahuluan}

Ikan Banggai Cardinal (Pterapogon kauderni) merupakan salah satu jenis ikan dari famili Apogonidae dengan penyebaran endemik terbataspada perairan laut dangkal,ditemukan di perairan Kepulauan Banggai (Hopkins at al., 2005).Habitat ikan Pterapogon kauderniadalah padang lamun dan terumbu karang, tergolong jenis ikan yang bersifat teritorial yaitu menempati suatu wilayah secara permanen, pergerakannya yang pasif dimana sebagian besar hidup berkelompok menempati duri-duri dari bulu babi (Diadema sp.) dan sebagian kecil hidup berasosiasi dengan anemone.Dalam perdagangan ikan hias international, ikan ini dikenal dengan nama umum Banggai Cardinal atau Caudem's cardinal atau Longfin cardinal (Sugama, 2008). Ikan Banggai Cardinal atau Banggai Cardinalfish/BCF memiliki nilai komersial yang cukup tinggi, harga ikan ini di daerah Bali dan Jakarta mencapai Rp. 5.000,-/ekor dan pasaran ekspor ke Singapura dan Jepang dapat mencapai US \$ 2,5/ekor (Poernomo dkk.,2003).

Populasi Pterapogon kauderni telah nyata mengalami penurunan relatif besar akibat kebutuhan pasar yang semakin tinggi dan penangkapan berlebihan di alam (overfishing).Pulau Banggai, Kepulauan Banggai merupakan pusat pengambilan ikan hias jenis Pterapogon kauderni dan mempunyai akses yang cukup baik bagi pulau-pulau disekitarnya (Lunn \& Moreau, 2004).Menurut Vagelli (2005) jumlah ikan ini menurun lebih dari $25 \%$ sejak awal mulainya perdagangan sekitar tahun 1990-an,diperkirakan pada tahun 2001-2004 diperdagangkan dengan jumlah individu 700.000-900.000 ikan per tahun. Bahkan dilaporkan ikan Banggai Cardinaltelah punah di Pulau Limbo sejak tahun 2004 (Allen and Donaldson, 2007). Pelestarian spesies ini sangat ramai dibicarakan di tingkat internasional karena adanya keinginan organisasi perlindungan flora dan fauna internasional untuk memasukkan ikan endemik ini ke dalam daftar Apendiks II CITES(Convention on International Trade in Endangered Species of Wild Fauna and Flora),pada Conference of Parties (CoP 14 CITES), tahun 2007. Namun keinginan tersebut ditunda dan Indonesia berkomitmen untuk mengembangkan pengelolaan Banggai cardinalfish secara lestari.

Ikan Banggai Cardinalhingga saat ini, sudah dapat ditemukan di beberapa perairan di Indonesia.Informasi keberadaan spesiesini di Teluk Ambon dengan melalui jalur perdagangan ikan hias. dari kabupaten Banggai Kepulauan secara keseluruhan diakses melalui Bitung Manado hingga sampai di Ambon.Masyarakat nelayan Ambon menyebut ikan inicapungan Banggai atau capungan Ambon kerena bentuk tubuhnya menyerupai capung,selain itu memiliki keunikan tersendiri dari segi tingkah laku, warna dan pola hidupnya (Makatipu, 2007).Penelitian ini bertujuan untuk mengungkapkan jenis dan populasi ikan Banggai Cardinal.

\section{Metode Penelitian}

\subsection{Pengambilan Data Ikan}

Pengamatan ikan Banggai Cardinal (Pterapogon kauderni) di perairan Teluk Ambon Dalam dilaksanakan bulan April2018. Metode yang digunakan adalah sensus visual yaitu garis transek ditarik (Line intercept transect) tegak lurus garis pantai dengan panjang transek 50 meter atau lebih(sesuai kondisi di lapangan) pada kedalaman antara 0,5-5 m.Karena spesies ini berada pada kedalaman 0,5-4,5 m, dan umumnya ditemukan pada kedalaman 1,5 m-2,5 m (Vagelli, 2005).Sensus ikan Banggai Cardinal dilakukan mengikuti garis transek dengan lebar pengamatan 2 meter yaitu $1 \mathrm{~m}$ dari sisi kiri dan $1 \mathrm{~m}$ dari sisi kanan garis transek.Luas bidang pengamatan 
ikan yang disensus dihitung berdasarkan panjang transek tiap lokasi.Parameter yang diamati meliputi; ukuran ikan, jumlah individu ikan dan jumlah bulu babi serta habitat lain.

\subsection{Analisis Data}

Jumlah individu ikan Banggai Cardinaldihitung untuk mengetahui densitas dan menduga kelimpahan populasi:

1. Densitas dihitung dengan menggunakan rumus:

$$
\begin{aligned}
& \mathrm{D}=\frac{\sum \mathrm{ni}}{\mathrm{Ld}} \\
& \text { dimana }: \mathrm{D}=\text { densitas }\left(\mathrm{ekor} / \mathrm{m}^{2}\right) \\
& \sum \mathrm{ni}=\text { jumlah ikan (ekor) } \\
& \mathrm{Ld} \quad=\text { luas daerah transek }\left(\mathrm{m}^{2}\right)
\end{aligned}
$$

2. Perhitungan kelimpahan populasi ikan melalui formulasi :

$$
\begin{gathered}
\mathrm{k}=\mathrm{D} \sum_{i=1}^{k} \mathrm{Lh} \\
\operatorname{dimana}: \mathrm{k}=\text { kelimpahan ikan }\left(\mathrm{ekor} / \mathrm{m}^{2}\right) \\
\mathrm{D}=\text { densitas }\left(\mathrm{ekor} / \mathrm{m}^{2}\right) \\
\mathrm{Lh}=\text { luas habitat }\left(\mathrm{m}^{2}\right)
\end{gathered}
$$

Pemetaanhabitat perairan dangkal dilakukan dengan menggunakan metode algoritma "depth invariant index" (Lyzenga, 1981)untuk membedakan objek yang berada di dasar perairan dangkal(Gambar1).

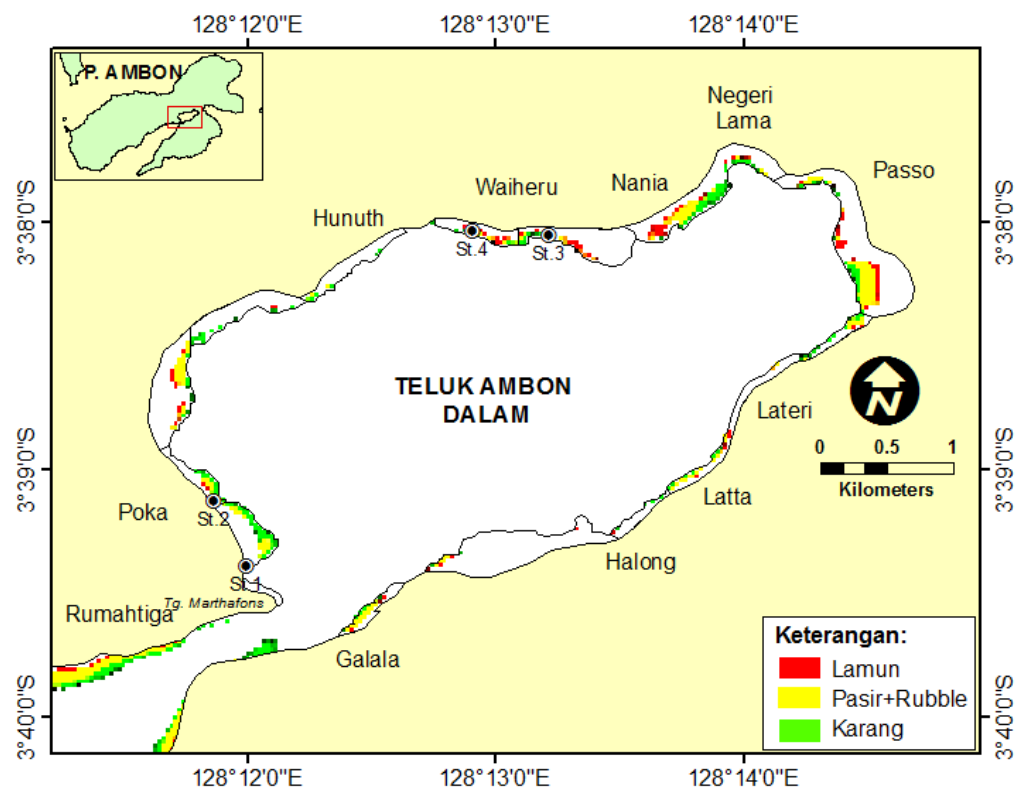

Gambar 1.Peta habitat perairan dangkal lokasi penelitian. 
Luasan habitat perairan dangkal pada lokasi penelitian dihitung dengan menggunakan analisis overlay sistem informasi geografi (SIG). Data dasar yang digunakan untuk pemetaanadalah citra Landsat 8 path/row 109/62perekaman Pebruari 2018.Data hidrologi diperoleh dari Pusat Penelinitan Laut Dalam-LIPI, Ambon.

\section{Hasil dan Pembahasan}

\subsection{Kondisi Lingkungan}

Pantai Poka dan Waiheru cukup terlindung karena berada diTeluk Ambon Dalam. Sirkulasi arus di kedua lokasi ini cukup lemah pada saat air pasang maupun surut. Pada perairan Poka ratarata kecepatan arus $0,032 \mathrm{~m} / \mathrm{s}$ dengan tingkat kekeruhan 1,25-2,78 NTU, sedangkan di Waiherurata-rata kecepatan arus 0,058 m/s dengan tingkat kekeruhan 3,49-4,45 NTU (Irawan dan Nganro, 2016).Substrat di daerah bakau adalah lumpur, pasir dan pecahan karang mati. Sedikit sumbangan lumpur berasal daerah bakau yang mengalir pada waktu hujan, sehingga cukup membantu proses penembalan substrat di daerah padang lamun.Substrat pada rataan padang lamun umumnya tersusun atas pasir berlumpur, pasir halus, pasir sedang sampai pasir kasar dan patahan karang(rubble).

Lebar rataan pasang surutpantai Poka mencapai \pm 200 meter dimulai dari garis pantai, bakau (10-20 m), padang lamun kemudian terumbu karang. Sebaran dan kondisi penutupan dasar perairan khusunya pasir+patahan karang, lamun dan karang dapat diketahui melalui nilai luasan obyek dari hasil analisis citra terklasifikasi. Berdasarkan hasilinterpretasi data citra Landsat 8 diketahui bahwa luas total rataan terumbu karang di Poka mencapai 6,08 ha dengan habitat (pasir+rubble 2,16ha, lamun 0,18 ha dan karang 3,74 ha) sedangkan di Waiheru4,68 ha (pasir+rubble 1,53 ha, lamun 2,16 ha dan karang 0,99 ha).Perairan pantai Poka khusunya Tg. Tiram memiliki padang lamun dan terumbu karang cukup luas di Teluk Ambon Dalam didominasi oleh marga Porites. Menurut Sutarna (1989) ditemukan 16 jenis karang,didominasi oleh jenisPorites lutea, Porites lichen, Lobophyllia hemprichii dan Goniopora lobata.Sedangkan lamun ditemukan 5 jenis, didominasi oleh jenis Enhalus Acoroides dan Thalassia hemprichii (Setyono, 1993; Tuhumury, 2008 dan Irawan, 2011).Daerah ini dijadikan masyarakat setempat untuk menjaring ikan dan menangkap biota-biota laut (kepiting, bulu babi, tiram (bivalvia) dan teripang.Berbeda dengan pantai Waiheru hanya ditemukan 2 jenis lamun didominasi oleh jenis Enhalus Acoroides (Tuhumury, 2008 dan Irawan, 2011).Lebar rataan pasang surut mencapai \pm 100 mdimulai dari darat adalah bakau (30-50 m), kemudian lamun disusul dengan terumbu karang.Disekitar perairan ini dijadikan masyarakat setempat untuk menjaring ikan dan merupakanlokasi budidaya oleh BPBL-Waiherudan SUPM-Waiheru.

PerairanPoka dan Waiheru masih layak bagi terumbu karang dan biota asosiasi lainnya termasuk ikan Banggai Cardinal (Pterapogon kauderni) untuk tumbuh dan berkembang.Berdasarkan hasil pengamatan beberapa parameter hidrologi(Tabel 1), menunjukkan bahwa nilai-nilai tersebut masih dalam ambang baku mutu air laut untuk biota laut (KepMen LH No. 51 tahun 2004). Suhu air antara 30,22-30,45 ${ }^{\circ} \mathrm{C}$, nilai ini masih dalam kisaran optimal untuk pertumbuhan dan kelangsungan hidup ikan. Menurut Vagelli dan Erdmann (2002) ikan akan melakukan pemijahan secara alami pada perairan dangkal kedalaman 1,5-2,5 m dengan suhu antara $28-31{ }^{\circ} \mathrm{C}$. Selanjutnya Brotowidjoyo, 1984 mengatakan bahwa kisaran suhu yang baik untuk budidaya adalah antara $20-30{ }^{\circ} \mathrm{C}$. Salinitasantara 33,03-33,16 \%o, nilai ini cukup tinggi namunmasihbaikuntukkehidupanorganisme lauttermasuk ikan Pterapogon 


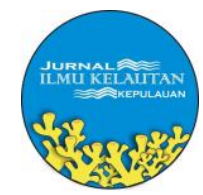

kauderni.Menurut Ndobe dan Moore (2006) ikan Pterapogon kauderni memiki kemampuan beradaptasi pada salinitas yang tinggi mencapai 36 \%o. Salinitas yang baik untuk pertumbuhan ikan Pterapogon kauderni adalah 27-31 \%o (Medinawati dkk., 2009).

Tabel 1.Hasil pengamatan parameter hidrologi dibandingkan dengan baku mutu air laut untuk biota laut (KepMen LH No. 51 tahun 2004).

\begin{tabular}{|c|c|c|c|c|c|}
\hline \multirow{3}{*}{ Parameter } & \multicolumn{4}{|c|}{ Hasil Pengamatan } & \multirow{3}{*}{$\begin{array}{l}\text { Baku Mutu Air Laut } \\
\text { Untuk Biota Laut (KepMen LH, 2004) }\end{array}$} \\
\hline & \multicolumn{2}{|c|}{ Poka } & \multicolumn{2}{|c|}{ Waiheru } & \\
\hline & St. 1 & St. 2 & St. 3 & St. 4 & \\
\hline Suhu, ${ }^{\circ} \mathrm{C}$ & 30,39 & 30,45 & 30,22 & 30,29 & Alami (Coral, lamun: 28-30) \\
\hline Salinitas, $\%$ & 33,16 & 33,11 & 33,03 & 33,09 & Alami (Coral, lamun : 33-34) \\
\hline $\mathrm{pH}$ & 8,44 & 8,43 & 8,46 & 8,49 & $7,0-8,5$ \\
\hline Oksigen, $\mathrm{mg} / \mathrm{l}$ & 4,91 & 5,09 & 4,68 & 4,61 & $>5$ \\
\hline
\end{tabular}

Nilai $\mathrm{pH}$ antara 8,43-8,49; kisaran nilai ini masih dalam batas aman untuk pertumbuhan dan kelangsungan hidup ikan Pterapogon kauderni. Menurut Ndobe (2011) ikan capungan hidup di kisaran $\mathrm{pH} 8,1-8,4$.Oksigen terlarut antara 4,61-5,09mg/l, nilai ini masih dalam kisaran yang layak untuk menunjang pertumbuhan dan kelangsugan hidup ikan Pterapogon kauderni. Menurut Rivai (1983) umumnya kandungan oksigen sebesar 5 mg/l dengan suhu air berkisar antara 20-30 ${ }^{\circ} \mathrm{C}$ relatif masih baik untuk kehidupan ikan-ikan, bahkan apabila dalam perairan tidak terdapat senyawa-senyawa yang bersifat toksik (tidak tercemar) kandungan oksigen sebesar $2 \mathrm{mg} / \mathrm{l}$ sudah cukup untuk mendukung kehidupan organisme perairan.

\subsection{SebarandanHabitat}

Ikan Banggai Cardinal (Pterapogon kauderni)belum banyak dikenal oleh masyarakat nelayan di Indonesia karena penyebarannya yang sangat terbatas. Pada awalnya hanya ditemukan di wilayah Sulawesi Tengah bagian timur, tepatnya di Kepulauan Banggai, karena itu spesies ini termasuk endemik. Namun demikian saat ini berbagai informasi menyebutkan ikan hias ini telah dapat ditemukan di lokasi lain yaitu perairan Bitung, Ambon, Kendari, Teluk Palu, Lampung, Kepulauan Seribu dan Gilimanuk Bali. Ikan Banggai Cardinal (Pterapogon kauderni) pertama kali ditemukan oleh Koumans, 1933 termasuk ikan air laut berukuran kecil, panjang standar mencapai 6,5 cm (Allen, 1997). Menurut beberapa informasi bahwa keberadaan ikan Banggai Cardinal di perairan Teluk Ambon Dalam, sebagai akibat dari bocornya keramba jaring apung, tempat penampungan ikan hias capungan. Pada perairan Teluk Ambon Dalam ikan Banggai Cardinal (Pterapogon kauderni)hanya ditemukan di dua lokasi pengamatan yaitu di Poka dan Waiheru. Dari hasil sensus di lokasi Poka yaitu stasiun 1 (Pelabuhan Ferry-Poka) tercatat masing-masing, 17 ekor ikan capung terdiri dari individu dewasa 6 ekor, individu muda 7 ekor dan anakan 4 ekor. Selanjutnya di stasiun 2 (Tg. Tiram-Poka) ditemukan 127 ekor dengan perincian individu dewasa 21 ekor, individu muda 56 ekor dan anakan 50 ekor. Pada lokasi Waiheru yaitu di stasiun 3 (SUPM-Waiheru) ditemukan 6 ekor terdiri dari individu dewasa 4 ekor dan individu muda 2 ekor. Sedangkan di stasiun 4 (BPBL-Waiheru) hanya ditemukan 9 ekor terdiri dari individu dewasa 6 ekor, individu muda 2 ekor dan anakan 1 ekor. Di Waiheruindividu bulu babi (Diadema) jarang ditemukan, dari hasil sensus hanya ditemukan 5 ekor, sedangkan di Poka ditemukan bulu babi cukup banyak yaitu 90 ekor (Tabel 2). 
Tabel 2. Jumlah individu Ikan Banggai Cardinal/BCF dan bulu babi(Diadema)/DIA diperairan Teluk Ambon Dalam, April2018.

\begin{tabular}{|c|c|c|c|c|c|c|c|c|}
\hline \multirow{2}{*}{ St. } & \multirow{2}{*}{ Lokasi } & \multicolumn{3}{|c|}{ Ukuran BCF } & \multicolumn{2}{|c|}{ Jumlah Individu } & \multirow{2}{*}{$\begin{array}{l}\text { Luas daerah } \\
\text { transek }\left(\mathrm{m}^{2}\right)\end{array}$} & \multirow{2}{*}{$\begin{array}{c}\text { Luas Habitat } \\
\left(\mathrm{m}^{2}\right)\end{array}$} \\
\hline & & $\mathrm{S}$ & $\mathrm{M}$ & $\mathrm{L}$ & $\mathrm{BCF}$ & DIA & & \\
\hline 1 & Pel. Ferry-Poka & 4 & 7 & 6 & 17 & 8 & 100 & 500 \\
\hline 2 & Tg. Tiram-Poka & 50 & 56 & 21 & 127 & 82 & 300 & 60300 \\
\hline 3 & SUPM-Waiheru & 0 & 2 & 4 & 6 & 2 & 120 & 25200 \\
\hline 4 & BPBL-Waiheru & 1 & 2 & 6 & 9 & 3 & 150 & 21600 \\
\hline & Jumlah & 55 & 67 & 37 & 159 & 95 & 670 & 107600 \\
\hline
\end{tabular}

Keterangan : Anakan $(\mathrm{S}=3-3,5 \mathrm{~cm})$; Ind. Muda $(\mathrm{M}=3,6-4 \mathrm{~cm})$ dan Ind. Dewasa $(\mathrm{L}=>4 \mathrm{~cm})$

Ikan Banggai Cardinal hidup bersimbiosis dengan bulu babi, jika tidak ada bulu babi dalam suatu perairan maka sulit untuk menemukan spesies ini. Menurut Ronny (komunikasi pribadi) bahwa Balai Perikanan Budidaya Laut Ambon telah menebarkan ikan Banggai Cardinal sejak tahun 2016, sebagai alternatif untuk kegiatan "Restocking". Penebarannya pada area dimana terdapat bulu babi di desa Suli, dan OSM Ambon masing-masing 500 ekor, namun saat melakukan pengamatan di kedua lokasi tersebut tidak ditemukan spesies ini demikian juga bulu babi. Diduga ikan Banggai Cardinal telah dimakan oleh beberapa jenis ikan cardinal lain. Menurut Vagelli (2002) ikan ini merupakan sumber makanan penting bagi beberapa spesies seperti Pterois (Scorpaenidae), Epinephelus merra (Serranidae), Cymbacephalus beauforti (Platycephalidaemorenas), Echidna nebulosa (Muraenidae), Synanceia horrida, Laticauda colubrine (Elapidae). Selain itu seringkali apabila ada ditemukan bulu babi, juga terdapat beberapa genera ikan kardinal ditempat tersebut (Vagelli, 2002).Umumnya ikan ini ditempati pada kedalaman kurang dari 5 meter di terumbu karang, padang lamun dan daerah terbuka pasir dimana banyak terdapat bulu babi.Menurut Vagelli \& Erdmann (2002) habitat asli ikan Banggai Cardinal hanya terbatas pada perairan danggkal $(0-5 \mathrm{~m})$ termasuk wilayah terumbu karang (rataan karang, tubir/puncak dan landau bagian atas), padang lamun dan laguna, bahkan tidak lebih dari kedalaman $8 \mathrm{~m}$. Ikan Banggai Cardinalmemiliki relung habitat di perairan karang namun demikian ikan ini juga sering dijumpai di ekosistem lamun dan tiang-tiang pancag dermaga.

Perairan Teluk Ambon Dalamditemukan 2-5 ekor ikan Pterapogon kauderni pada seekor bulu babi (Diadema) berlindung dengan menempati duri-durinya.Ikan Banggai Cardinal hidup bersimbiosis dengan bulu babi (Diadema),simbiosis dilakukan dengan cara mengupayakan agar garis hitam pekat pada tubuh mereka membaur membentuk garis lurus dengan salah satu duri bulu babi yang bertujuan untuk penyamaran dan perlindungan dari serangan predator. Selain bulu babi, spesies ini juga memiliki tempat perlindungan lain yaitu anemon laut dengan cara memanfaatkan tubuh mereka yang kecil agar dapat menyelinap diantara helaian anemon laut, hidup bersama dengan ikan dan udang kecil yang berada pada anemon (Vagelli, 2002).Perilaku hidupnya sedentary (menetap) dan melayang berdekatan dengan microhabitat pelindung, jika merasa terancam atau tertanggu cenderung mencari pelindung pada symbiont, hidup berkelompok dan tidak berpindah jauh dari tempat asalnya.Pterapogon kauderni merupakan ikan nokturnal aktif yaitu mencari makan pada malam hari (Allen dan Steene, 1995). Makanannya berupa plankton, mikro krustasea dan ikan kecil. Ikan ini juga ditemukan berasosiasi dengan 


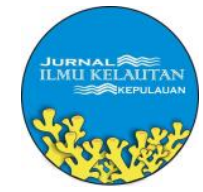

karang bercabang, bintang laut dan akar mangrove. Selain itu habitat dengan perairan yang tenang dan terlindung.

\subsection{Densitas dan Dugaan Populasi}

Berdasarkan hasil perhitungan densitas diketahui bahwa lokasi Poka yaitu pada stasiun 2 menunjukkan densitas ikan Pterapogon kaudernimencapai 0,42 ekor $/ \mathrm{m}^{2}$, lebih tinggi daristasiun 1dengan densitas0,17 ekor/ $\mathrm{m}^{2}$.Ikan hias ini umumnya ditemukan pada daerah lamun dan terumbu karang dimana banyak terdapat bulu babi.Dalam satu kelompok bulu babi ditemukan ikan Banggai Cardinal sebanyak10-20 ekor di stasiun 2, dengan densitas bulu babi mencapai 0,27 ekor/ $\mathrm{m}^{2}$, berbeda dengan stasiun 1 dengan densitas bulu babi 0,08 ekor $/ \mathrm{m}^{2}$ (Gambar 2). Kolm \& Berglund, 2003 mengatakan bahwa densitas ikan hias ini behubungan positif dengan densitas bulu babi.Selain terdapat microhabitat utamanya perairannya cukup tenang dan terlindung dengan intensitas cahaya matahari yang sangat baik. Sedangkandi Waiheru hanya memiliki nilai densitas ikan Banggai Cardinal 0,05-0,06 ekor/m²dan densitas bulu babi 0,017-0,02 ekor/m².Rendahnya densitas ikan Pterapogon kauderniselain dikarenakan rendahnya densitas bulu babijuga dipengaruhi faktor lingkungan diantaranya penutupan dasar perairan.Substrat dasar di lokasi inididominasi oleh lumpur pasiran sehinggasering terjadi kekeruhanhingga mencapai 4,45 NTU (Irawan dan Nganro, 2016). Kekeruhan air dapat menyebabkan ikan sulit bernafas karena insangnya tertutup oleh partikel-partikel lumpur. Kekeruhan air semakin tinggidapat menghambat masuknya cahaya kedalam air mengakibatkan proses fotosintesis fitoplankton terhambat sehingga kadar oksigen terlarut rendah.Kekeruhan air laut untuk biota laut termasuk ikan Pterapogon kauderni yaitu < 5 NTU (KepMen LH No. 51 tahun 2004).

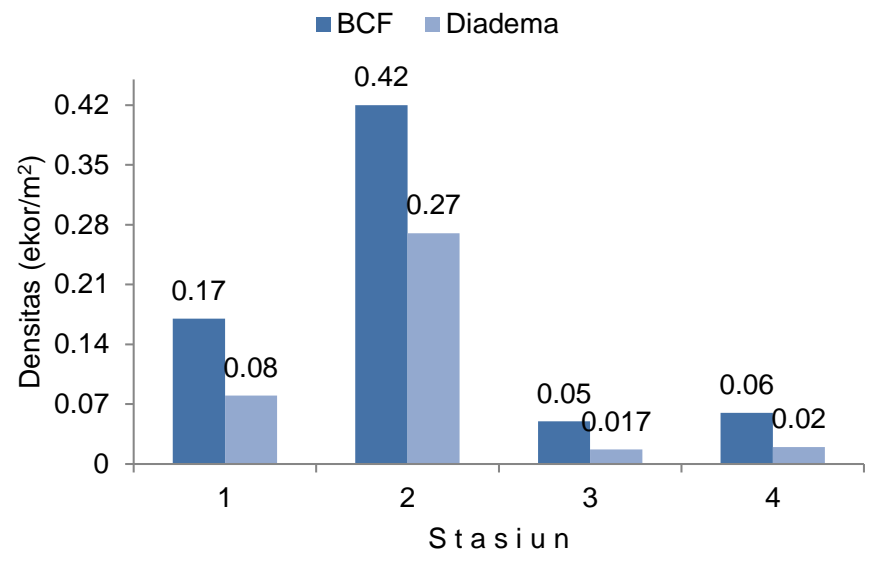

Gambar 2.Densitas ikan Pterapogon kauderni(BCF) dan bulu babi (Diadema). diperairan Teluk Ambon Dalam.

Densitas ikan Pterapogon kaudernidi Poka dan Waiheru, perairan Teluk Ambon Dalamdengan nilai rata-rata $0,18 \mathrm{ekor} / \mathrm{m}^{2}$ lebih tinggi bila dibandingkan hasil survei pada 7 lokasi di Kepulauan Banggai yang memiliki densitas ikanPterapogon kauderni200-700 ekor/ha dengan densitas rata-rata $0,07 \mathrm{ekor} / \mathrm{m}^{2}$ (Vagelli, 2005). Namun lebih rendah bila dibandingkan dengan hasil penelitian yang pernah dilakukan oleh Lunn \& Moreau, 2004 di kawasan lindung (teluk kecil disebelah barat daya Kepulauan Banggai) yang memiliki densitas 0,25-1,22 ekor/m² dengan rata-rata 0,63 $\pm 0,39 \mathrm{ekor} / \mathrm{m}^{2}$.Demikian juga penelitian dilakukan oleh Wijaya, 2010pada 4 lokasi lokasi di Kepulauan Banggai yaitu 1 lokasi di pulau Bandang dan 3 lokasi di pulau Banggai yang 


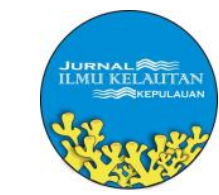

memiliki densitas ikan Pterapogon kauderni 0,31-0,87 ekor/m² dengan rata-rata $0,56 \pm 0,25 \mathrm{ekor} / \mathrm{m}^{2}$.

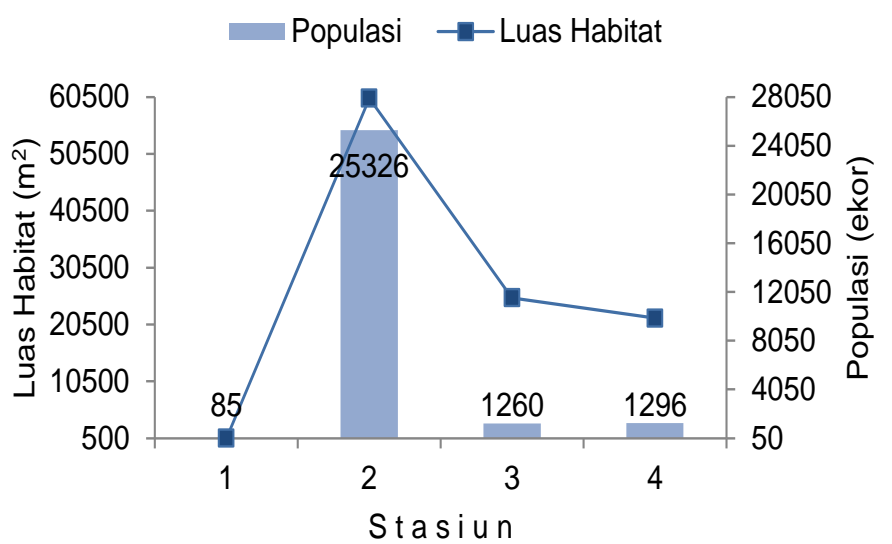

Gambar 3.Populasi Pterapogon kaudernidi perairan Teluk Ambon Dalam.

Populasi tertinggi ikan Pterapogon kaudernidi perairan Teluk Ambon Dalam tercatat pada stasiun 2 dengan dugaan populasi 25.326 ekor dengan nilai densitas dan luasan habitat yang juga lebih besar dibandingkan dengan stasiun penelitian lainnya. Sedangkan dugaan populasi terendah 85 ekor terdapat pada stasiun 1, yang merupakan lokasi terdekat dengan aktifitas masyarakat. Adapundi stasiun 3 dan stasiun 4, walaupun nilai densitas rendah dibandingkan dengan stasiun 1, namun memiliki dugaan populasi lebih besar, dikarenakan luasan habitat di kedua stasiun tersebut lebih besar dibandingkan dengan stasiun 1 (Gambar 3).Kelimpahan populasi ikan Banggai Cardinal di perairan Teluk Ambon Dalammencapai 27.967 ekordengan luasan habitat $0,108 \mathrm{~km}^{2}$. Lebih tinggi populasinya bila dibandingkan dengan kedua pulau kecil disekitar pulau Banggai yaitu pulau Kenau15.680 ekor dengan luasan habitat 0,224 $\mathrm{km}^{2}$ dan pulau Bakakan 3.920 ekor dengan luasan habitat $0,056 \mathrm{~km}^{2}$, namunmasih rendah jika dibandingkan dengan pulau Banggai 258.720 ekor (Vagelli, 2005). Rendahnya populasi Pterapogon kauderni di perairan Teluk Ambon Dalam diduga ikan ini telah ditangkap oleh nelayan lokal untuk dijual ke pedagang ikan hias.Selain itu menurut informasi bahwa ikan ini juga ditangkap dan dipelihara oleh BPBL-Waiheruuntuk kegiatan "restocking". Menurut Vagelli, 2005 Pterapogon kauderni merupakan spesies yang memiliki keunikan karakteristik reproduksi sehingga sangat rentan apabila dieksploitasi secara berlebihan. Ikan ini menghasilkan keturunan setelah mencapai ukuran panjang standar 3,5 cm dengan umur 9-12 bulan. Ikan Banggai Cardinal dapat hidup selama 2-4 tahun dan bereproduksi sepanjang tahun selama adanya kecukupan makanan. Reproduksi ikan erat kaitannya dengan perkembangan gonad, aktifitas reproduksi cukup tinggi terutama pada bulan Juli, September dan Oktober sedangkan bulan Juni, Agustus dan Nopember aktifitas reproduksinya rendah (Rusdi, 2005). Oleh karena itu diingatkan bagi para nelayan yang menangkap ikan Pterapogon kauderni pada bulan-bulan tersebut agar jangan sampai terjadi "overfishing". 


\section{Kesimpulan}

Populasi ikan Banggai Cardinal (Pterapogon kauderni) di perairan Teluk Ambon Dalam masih dalam jumlah yang terbatas.Oleh karena itu perlu dilakukan kegiatan budidaya, hal ini dimaksudkan untuk mengurangi tekanan terhadap populasi alami, di samping sebagai alternatif untuk kegiatan "Restocking". Lokasi yang sangat cocok untuk kegiatan "Restocking" ikan Banggai Cardinal (Pterapogon kauderni) di Teluk Ambon Dalam adalahTg. Tiram-Poka, selain terdapat habitat utamanya perairannya cukup tenang dan terlindung dengan kualitas airnya pada kisaran yang masih memenuhi standar baku mutu air laut untuk biota laut.

\section{Daftar Pustaka}

Allen, G.R. and R.C. Steene, 1995. Notes on the Ecology and Behaviours of the Indonesian cardinalfish (Apogonidae) Pterapogon kauderni Koumans. Revue fr. Aquariol.,22(1-2): 79.

Allen, G.R., 1997. Marine Fishes of South-East Asia; A Field Guide for Anglers and Divers. Western Australian Museum, Perth : 292 pp.

Allen, G.R. and T.J. Donaldson, 2007.Pterapogon kauderni.In IUCN 2008.IUCN Red List Threatened Species.

Brotowidjoyo.1984. Pengantar Lingkungan Perairan dan Budidaya Air. Liberty, Yogyakarta

Hopkins, S., H. Ako and C.S. Tamaru, 2005. Manual for the Production of the Banggai Cardinalfish, Pterapogon kauderni, in Hawai'i. 28p.

Irawan, A. 2011.Komunitas lamun di Teluk Ambon.Perairan Maluku dan Sekitarnya.Hal.61-69.

Irawan, A dan N. R. Nganro, 2016.Sebaran lamun di Teluk Ambon Dalam.Jurnal Ilmu dan Teknologi Kelautan Tropis, 8(1):99-114.

Kolm, N.and Berglund, 2003. Wild Populations of a Reef Fish Suffer from the "Nondestructive" Aquarium Trade Fishery. Conservation Biology, 17(5):910-914.

Koumans, F.P. 1933. On a new genus and species of Apogonidae.Zool. Med. Mus. Leiden 16:78 pp.

Lunn, K. \& Moreau, M., 2004. Unmonitored Trade in Marine Ornamental Fishes: the Case of Indonesia's Banggai Cardinalfish (Pterapogon Kauderni). Coral Reefs. 23:344-351

Lyzenga, D.R., 1981. Remote Sensing of Bottom Reflectance and Water Attenuation Parameters in Shallow Water Using Aircraft and Landsat Data. International Journal of Remote Sensing 2, pp. 71-82.

Makatipu, P.C., 2007. Mengenal Ikan Hias Capungan Banggai (Pterapogon Kauderni). Oseana, 32(3):1-7.

Medinawati, Ndobe, S. dan Gamgulu, A., 2009. Pertumbuhan ikan Kardinal Banggai (Pterapogon Kauderni) yang dipelihara pada salinitas yang berbeda dalam wadah terkontrol. Jurnal Akuakultur Indonesia, 8(2):193-198.

Ndobe, S. dan Moore, A., 2006. Potensi dan Pentingnya Pengembangan Budidaya In-Situ Pterapogon kauderni (Banggai Cardinalfish).Prosiding Konferensi Nasional Akuakultur 2005 Makasar.Masyarakat Akuakultur Indonesia (MAI). Badan Penerbit Universitas Diponegoro, Semarang.

Ndobe S. 2011. Pertumbuhan ikan hias Banggai Cardinalfish (Pterapogon kauderni) pada media pemeliharaan salinitas yang berbeda. ISSN 1979-5971. 
Poernomo, A.S., Mardlijah, MX. Linting dan Widjopriono, 2003.Ikan Hias Laut Indonesia.Penebar Swadaya, Jakarta: 182 hal.

Riva'i, R.S. dan Pertagunawan, K., 1983. Biologi Perikanan I, Penerbit CV. Kayago, Jakarta, 143 hal.

Rusdi, 2005.Studi beberapa aspek biologi ikan kardinal Banggai (Pterapogon kauderni) di Kabupaten Banggai Kepulauan, Propinsi Sulawesi Tengah.

Setyono, D.E.D., 1993. Distribusi dan dominasi lamun (Seagrass) di Teluk Ambon.Perairan Maluku dan Sekitarnya. BPPSDL, Puslitbang Oseanologi-LIPI: 61-68.

Sugama, K., 2008. Pemijahan dan pembesaran anak ikan cardinak banggai (Pterapogon kauderni). J. Ris. Akuakultur, 3(1): 83-90.

Sutarna, I.N., 1989. Kondisi karang di Teluk Ambon bagian dalam, Pulau Ambon. Dalam: Teluk Ambon II, Biologi, Perikanan, Oseangrafi dan Geologi. (Soemodihardjo, S.; S. Birowo dan K. Romimohtarto, Eds). BPPSDL, Puslitbang Oseanologi-LIPI: 18-22.

Tuhumury, S.F. 2008.Status komunitas lamun di perairan pantai Teluk Ambon Bagian Dalam (TAD). Ichthyos, 7(2): 85-88.

Vagelli A.A., 2002. Notes on the biology, geographic distribution, and conservation status of the Banggai cardinalfish Pterapogon kauderni Koumans 1933, with comments on captive breeding techniques. Tropical Fish Hobbyist, 84-88.

Vagelli A.A., 2005. Reproductive Biology, Geographic Distribution and Ecology of the Banggai Cardinalfish Pterapogon kauderni Koumans, 1933 (Perciformes, Apogonidae), with Considerations on the Conservation Status of this Species on its Natural Habitat.[Dissertation]. Buenos Aires (AR): University of Buenos Aires.276 pp.

Vagelli A.A., 2005. The Banggai Conservation Project.Working for the creation of network of small marine sanctuaries in the Banggai Archipelago, Indonesia.Communique. Am. Zoo \& Aquarium Assoc. July 2005: 47-48.

Vagelli A.A dan Erdmann M.V, 2002.First comprehensive ecological survey of the Banggai Cardinalfish, Pterapogon kauderni.Environmental Biology of Fishes, 63:1-8.

Wijaya, I., 2010. Analisis pemanfaatan ikan banggai cardinal (Pterapogon kauderni Koumans, 1933) di Pulau Banggai, Sulawesi Tengah.Tesis.Institut Pertanian Bogor.73 hal. 